\title{
Pengaruh Periklanan, Celebrity Endorser dan Label Halal Terhadap Keputusan Pembelian Shampo Sunsilk Hijab pada Mahasiswa Universitas Muhammadiyah Palopo
}

\author{
Risna \\ Universitas Muhammadiyah Palopo \\ risnabolong@gmail.com \\ Rahmad Solling Hamid \\ Universitas Muhammadiyah Palopo \\ rahmadshamid@umpalopo.ac.id

\section{Salju \\ Universitas Muhammadiyah Palopo \\ salju@umpalopo.ac.id}

\begin{abstract}
Abstrak Tujuan penelitian ini yaitu untuk mengetahui pengaruh periklanan, Celebrity Endorser, dan label halal terhadap keputusan pembelian konsumen shampo sunsilk hijab dikalangan mahasiswa Fakultas Ekonomi dan Bisnis. Populasi dalam penelitian ini yaitu Mahasiswa pada Fakultas Ekonomi Dan Bisnis Universitas Muhammadiyah Palopo Angkatan tahun 2016 berjumlah 253 Mahasiswa. Penentuan jumlah sampel yaitu menggunakan rumus Slovin pada tingkat presisi 5\% diperoleh sebanyak 155 sampel. Metode analisis yang digunakan yaitu analsiis regresi linier berganda. Hasil penelitian diperoleh informasi bahwa berdasarkan uji simultan variabel periklanan, Celebrity Endorser, dan label halal berpengaruh signifikan terhadap keputusan pembelian, selanjutnya berdasarkan uji parsial yaitu untuk periklanan dan celebrity endorser memiliki dampak positif dan signifikan pada keputusan pembelian, sedangkan label harga memiliki dampak positif tidak signifikan pada keputusan pembelian.

Kata Kunci Periklanan, Celebrity Endorser, label halal dan Keputusan Pembelian
\end{abstract}

\section{PENDAHULUAN}

Dalam dunia bisnis, perusahaan dominan memiliki pengaruh yang sangat besar terhadap aktivitas pemasaran. Perusahaan harus dituntut untuk memiliki kemampuan dalam berinovasi, kreatif dan berkompetisi secara aktif saat menciptakan produk agar memiliki keunikan dan keunggulan yang dapat diperlihatkan kepada konsumen. Untuk dapat bersaing, perusahaan harus mengembangkan strategi untuk menguasai pangsa pasar. Dengan adanya strategi pasar memungkinkan produsen mencapai tujuan yang akan dicapai. Dari setiap kegiatan pemasaran merupakan ujung tombak keberhasilan perusahaan. Perusahaan harus tanggap dan cepat mengomunikasikan produknya secara tepat, agar dengan mudah diketahui oleh konsumen (Zulkifli1, 2019).

Dalam kondisi ini perusahaan berpikir untuk membuat suatu produk yang sangat di butuhkan oleh konsumen adalah shampo. Shampoo merupakan salah satu kebutuhan 
kebersihan sehari-hari konsumen untuk perawatan rambut. Strategi yang sangat penting untuk mengembangkan rencana pemasaran adalah melakukan segmentasi pasar. Pangsa pasar sampo yang luas telah menarik banyak perusahaan untuk memasuki industri ini. Persaingan bisnis dalam industri yang semakin ketat membuat beberapa produsen merek shampo bersaing untuk memenangkan persaingan pangsa pasar. Namun demikian hanya terdapat beberapa produsen dengan merek shampo saja yang berhasil memenangkan persaingan tersebut (Rizki \& Agung, 2017). Kualitas produk memiliki makna yaitu bahwa produk yang disediakan memiliki nilai jual lebih dibenak konsumen. Perusahaan berupaya untuk tetap fokus pada kualitas produk yang ditawarkan serta melakukan perbandingan dengan perusahaan pesaing. Tidak hanya merek yang menentukan keputusan pembelian, kualitas produk merupakan faktor berdampak pada keputusan membeli sebuah produk.

Keputusan pembelian yaitu sebuah keputusan yang dibuat calon konsumen dalam memilih produk. Saat memahami perilaku konsumen, seseorang akan terpengaruh dalam banyak hal saat membuat keputusan pembelian untuk produk dan merek (Zulkifli, I, 2019). Berdasarkan observase prapenelitian yang melakukan dan menjelaskan perusahaan yang bergerak di bidang periklanan, celebrity endorser dan label halal mulai berlombsa-lomba mengeluarkan ide demi memuaskan kepuasan konsumen. Periklanan adalah salah satu ide promosi paling umum yang digunakan oleh semua perusahaan untuk menginformasikan, membujuk, dan mempertahankan setiap konsumen. Periklanan yaitu bentuk komunikasi dalam pemasaran yang mengacu pada segala bentuk penerapan teknologi komunikasi yang digunakan pemasar dalam menyampaikan informasi kepada konsumennya. Konsumen akan terbiasa dengan periklanan penjualan sehingga respon mereka terhadap aktivitas periklanan penjualan cenderung dengan komunikasi konsumen. Akan tetapi periklanan mempunyai banyak varian seperti komunikasi, insentif (Zulkifli, I, 2019). Dalam sebuah produk, unsur atribut produk tertentu memiliki dampak pada keputusan pembelian dengan memperhatikan kualitas produk, harga, merek dan fungsi. Bagi konsumen, inilah pertimbangan terpenting sebelum mengambil keputusan pembelian produk. Periklanan yang dapat dilakukan oleh perusahaan untuk mengkomunikasikan serta menggunakaan bantuan celebrity endorser supaya produknya bisa berjalan dengan efektif.

Celebrity endorser adalah salah satu cara yang lagi masa kini untuk meenyampaikan pesan atau mengajurkan kosumen untuk membeli produk tersebut. Celebrity endorser adalah tokoh terkenal di berbagai bidang, dan karena kinerja mereka, mereka dapat memengaruhi pembelian produk. Penggunaan selebritis dalam periklanan dapat membantu perusahaan mencapai tujuan dalam memperkenalkan produknya kepada konsumen, sehingga menarik informasi yang jelas tentang produk yang diminati konsumen, dan memperoleh respon positif dari konsumen (Andrianto, 2016). Kemasan produk yang baik dianggap mampu meyakinkan konsumen untuk membeli, dan berkaitan dengan derajat kehalalan produk tersebut.

Label halal berkaitan tentang pengaturan derajat kehalalan suatu produk menurut hukum Islam berdasarkan fatwa Majelis Ulama Indonesia. Untuk mendapatkan lisensi, label halal harus dicantumkan pada kemasan produk instan pemerintah yang telah disetujui untuk mendapatkan sertifikat halal. Sertifikat halal bertujuan untuk mengetahui status halal tidaknya suatu produk agar konsumen memiiki keyakinan pada produk tersebut. Bagi produsen, memahami kebutuhan setiap konsumen akan produk 
atau jasa, dan memahami karakteristik masing-masing pembeli. Pemilihan variabel label harga dikarenakan peneliti menganggap bahwa faktor tersebut memiliki pengaruh yang penting pada keputusan pembelian (Khuwaroh, 2018).

Tabel 1. Produk Shampoo

\begin{tabular}{|c|l|l|l|}
\hline Merk & 2016 & 2017 & 2018 \\
\hline Sunsilk & $60,7 \%$ & $27,5 \%$ & $32,3 \%$ \\
\hline Pantene & $58,7 \%$ & $16,3 \%$ & $23,1 \%$ \\
\hline Clear & $23,1 \%$ & $23,1 \%$ & $31,9 \%$ \\
\hline Lifeboy & $53,4 \%$ & $12,8 \%$ & $18,1 \%$ \\
\hline Rejoice & $51,3 \%$ & $6,4 \%$ & $15,9 \%$ \\
\hline
\end{tabular}

(Sumber: Top Brand Award, 2018)

Seperti yang dapat dilihat dari Tabel 1, pangsa pasar sampo Sunsilk mengalami peningkatan. Pesaing produk sampo Sunsilk diantranya Clear, Pantene, Lifeboy serta Joy. Untuk 2016, sampo Sunsilk memiliki pangsa pasar yang meningkat cukup signifikan sebesar $60,7 \%$. Pangsa pasar produk sampo lainnya masih tertinggal jauh dari produk sampo Sunsilk dengan peringkat teratas. Pada 2017, pangsa pasar sampo Sunsilk turun $27,5 \%$. Pada tahun 2018, shampo sunsilk mengalami kenaikan kembali. Walaupun tidak setinggi pangsa pasar sebelumnya tapi cukup kembali mengalami kenaikan yaitu sebesar $32,3 \%$. Dari data di atas terlihat bahwa untuk penjualan shampo sunsilk dalam kondisi fluktuasi dari tahun 2016 hingga tahun 2018.

Telah hadri berbagai jenis merek shampo yang telah dikenal dan digunakan oleh masyarakat seperti Pantene, Sunsilk, Clear, Lifebuoy dan sebagainya. Hal itu juga dikarenakan sejauh ini respon pasar terhadap hijab terbilang bagus. Periklanan shampo Sunsilk Hijab Clean and Fresh terus berpusaya melakukan inovasi salah satunya dengan menggunakan celebrity endorser artis yang memakai style hijab masa kini shampo Sunsilk Hijab Clean and Fresh. Hal tersebut menunjukkan bahwa sunsilk mampu memenangkan persaingan di industri shampo. Oleh karena itu, penulis memilih melakukan fenomena penelitian terhadap mahasiswa Universitas Muhammadiyah Palopo sudah banyak menggunakan Shampo Hijab Sunsilk Clean And Fresh dan alasannya karena mereka Shampo Hijab Sunsilk Clean and Fresh cocok dengan rambut mereka yang menggunakan hijab sehingga mengurangi bauk, lepek dan ketombe dan ada juga yang tertarik dengan periklanannya karena pada periklanan Shampo Hijab Sunsilk Clean And Fresh oleh wanita muslimah yang menggunakan hijab dan Sunsilk Hijab Sunslik Clean And Fresh setiap tahunnya menyelenggarakan model Sunsilk Hijab Hunt sehingga sangat memotivasi mereka dalam berhijab dan memakai Shampo Hijab Sunsilk Clean And Fresh.

Beberapa hasil penelitian sebelumnya yang telah mengkaji pengaruh periklanan, celebrity endorser dan label halal terhadap keputusan pembelian konsumen, ternyata masih terdapat perbedaan hasil penelitian atau adanya (gap). Diantaranya, penelitian yang dilakukan oleh, Zulkifli (2019); (Zubaidah, 2016.) menghasilkan temuan bahwa periklanan memiliki dampak positif dan signifikan pada keputusan pembelian Shampo. Sedangkan menurut Choirul Lutviansah (2016) bahwa periklanan tidak memiliki dampak signifikan pada keputusan pembelian. Selanjutya hasil temuan penelitian Oliver (2013) yaitu label halal tidak berdampak signifikan pada keputusan pembelian shampo. 
Berbeda dengan penelitian yang dilakukan (Saputra, 2017) bahwa label halal berdampak signifikan terhadap keputusan pembelian shampo. Sedangkan menurut Rizki \& Agung (2017); (Wulandari \& Nurcahya, 2015) dengan hasil temuan penelitian bahwa celebrity endorser memiliki dampak signifikan pada keputusan pembelian shampo. Berbeda pada temuan yang dilakukan oleh Kalangi Tamengkel, \& Walangitan (2019) menunjukkan bahwa tidak ada dampak positif signifikan celebrity endorser pada keputusan pembelian sampo. Dari latar belakang dan adanya gap yang sudah diuraikan diatas, maka tujuan penelitian ini yaitu untuk mengetahui dampak dari periklanan, celebrity endorser, serta label halal pada keputusan pembelian yang dilakukan oleh Mahasiswa Universitas Muhammadiyah Palopo.

\section{LANDASAN TEORI \\ 1. Periklanan}

Periklanan merupakan segala biaya yang harus dikeluarkan sponsor untuk melakukan presentasi dan promosi nonpribadi dalam bentuk gagasan, barang atau jasa (Saputra, 2017). Menurut Bearden dan Ingram (2007) periklanan merupakan bagian dari komunikasi pemasaran yang bersifat persuasif, nonpersonal, serta dibayar sponsor dan disebarkan melalui media komunikasi massa dengan tujuan mempromosikan pemakaian suatu produk. Dari definisi diatas dapat disimpulkan bahwa Periklanan merupakan salah satu strategi untuk menghadapi persaingan. Kegiatan periklanan merupakan alat yang bertujuan untuk memperluas komunikasi antara pembeli dan penjual, dengan tujuan untuk memenuhi keinginan mereka.

Kotler dan Armstrong (2012) mengklasifikasikan fungsi dan tujuan periklanan adalah sebagai berikut:

a. Memberi Informasi (Infromative Advertising)

Membuat konsumen sadar akan produk baru, mendidik mereka tentang berbagai fitur dan manfaat produk serta memfasilitasi penciptaan citra produk yang positif.

b. Mempersuasi (Persuasive Advertising)

Membujuk konsumen untuk mencoba produk yang diperiklankan dengan mempersuasikan sehingga memengaruhi konsumen.

c. Mengingatkan (Reminder Advertising)

Menjaga agar produk perusahaan tetap segar dalam ingatan para konsumen. Menyampaikan peranan sebagai memfasilitasi upaya lain dari perusahaan dalam proses salah satu komunikasi pemasaran.

\section{Selebrity Endorser}

Penggunaan selebrity pada sebuah produk endorser harus melalui berbagai pertimbangan, diantaranya yaitu tingkat popularitas dengan permasalahan apakah selebriti yang dipilih dapat mewakili karakter produk yang sedang diiklankan (Rachma \& Hufron, 2016). Menurut Shimp (2010) endorser adalah pendukung periklanan atau yang dikenal juga sebagai bintang periklanann untuk mendukung suatu produk. Sedangkan selebriti adalah tokoh (actor penghibur atau atlet) yang terkenal atau dikenal karena prestasinya dalam bidang - bidang yang berbeda dari produk yang di dukungnya (shimp, 2010). Selebriti dipandang sebagai individu yang disenangi oleh masyarakat dan memiliki keunggulan atraktif yang membedakannya dari individu lain. Para ahli mengemukakan pengertiannya mengenai celebrity endorser. Suryadi (2006) mendefinisikan bahwa endorser adalah icon atau sering disebut juga sebagai direct source 
(sumber langsung) untuk mengantarkan sebuah pesan dan atau memperagakan sebuah produk atau jasa dalam kegiatan promosi yang bertujuan untuk mendukung efektifitas penyampaian pesan produk. Berdasarkan pengertian celebrity endorser menurut para ahli di atas dapat di simpulkan bahwa. Celebrity Endorser yaitu penggunaan seorang artis, entertainer atau atlet yang dikenal pada bidangnya masing-masing untuk mempromosikan sebuah produk yang di periklanankan. Endorser adalah orang yang terlibat dalam penyampaian pesan, baik secara langsung ataupun tidak langsung.

Jenis endorser menurut Shimp (2007) dibagi menjadi tiga kelompok yaitu:

\section{Orang Biasa}

Orang biasa merupakan orang yang tidak berasal dari kalangan selebriti yang disebut juga sebagai non-selebriti yang menggunakan atau mendukung suatu produk.

2. Selebriti

Selebriti adalah seorang tokoh yang dikenal oleh masyarakat dalam bidang yang berbeda-beda.

3. Para Ahli

Para ahli adalah orang-orang yang pendapatnya tentang suatu produk menjadi patokan dan dituruti oleh orang-orang yang kurang tahu tentang produk tersebut. Biasanya mereka mempunyai peran yang penting dalam komunikasi dari mulut ke mulut.

Menurut (Shimp, 2007) terdapat beberapa peran selebriti dalam sebuah periklanan:

1. Testimonial, yaitu apabila secara personal selebriti menggunakansebuah produk, dari pengalaman tersebut selebrity akan memberikan kesaksian yang berkaitan dengan kualitas dan manfaat produk atau merek yang diperiklanankan.

2. Endorsement, yaitu selebrity yang memiliki popularitas akan diminta untuk memerankan sebuah iklan produk meskipun selebrity tersebut belum memiliki keahlian pada bidang tersebut.

3. Actor, yaitu perusahaan akan meminta kepada selebriti dengan tujuan untuk memperkenalkan sebuah produk atau merek tertentu yang berhubungan dengan peran yang ia perankan pada program tayangan pada produk atau merek tertentu.

4. Spokeperson, yaitu seorang selebriti yang diminta oleh perusahaan untuk mengenalkan produk, merek dalam kurun waktu tertentu masuk dalam kelompok peran spokeperson. Penampilan mereka akan diasosiasikan pada merek atau produk yang di promosikan.

\section{Label Halal}

Pemberian label halal untuk suatu produk dilakukan dengan maksud untuk menyediakan perlindungan bagi kalangan umat muslim. Adanya label halal yang tertera pada kemasan produk, maka akan berdampak pada keputusan konsumen khususnya masyarakat muslim untuk memilih mengunakan suatu produk. Munculnya rasa aman dan nyaman dalam mengkonsumsi produk tersebut akan meningkatkan kepercayaan serta minat belinya (Afrian2017). Label halal adalah merek sebagai nama, lambang, atau desain, yang dimaksudkan untuk mengidentifikasikan barang atau jasa dari salah satu penjual dan mendiferensiasikan mereka dari para pesaing Kotler dan Amstrong (2012). Label halal adalah pencantuman tulisan atau pernyataan halal pada kemasan produk untuk menunjukkan bahwa produk yang dimaksud berstatus sebagai produk halal.

Berdasarkan pengertian label halal menurut para ahli di atas dapat di simpulkan, label halal merupakan suatu keterangan yang melengkapi suatu kemasan barang yang 
berisi tentang bahan-bahan yang digunakan untuk membuat barang tersebut. Pemahaman yang semakin baik tentang agama makin membuat konsumen muslim menjadi semakin selektif dalam pemilihan produk yang dikonsumsi. Khusus di Indonesia, konsumen Muslim di lindungi oleh lembaga yang secara khusus bertugas untuk mengaudit produkproduk yang dikonsumsi oleh konsumen Muslim di Indonesia, Peredaran produk shampo. Majelis Ulama Indonesia (LPPOM-MUI). Artinya produk tersebut secara proses sudah tidak mengandung unsur- unsur yang dilarang oleh ajaran Agama Islam, serta aman dikonsumsi oleh konsumen muslim (Afrian 2017). Menurut Kotler dan Amstrong (2007) menyatakan bahwa tujuan label halal yaitu:

1. Memberi konten informasi mengenai komponen isi suatu produk yang telah diberikan label tanpa harus memeriksa isi produk.

2. Memiliki fungsi sebagai media komunikasi antara produsen dan konsumen yang berhubungan mengenai hal-hal yang sifatnya diketahui pembeli atau konsumen.

3. Memberikan suatu pengarahan bagi konsumen hingga diperoleh fungsi produk yang optimal.

4. Media periklanan yang dimiliki produsen

5. Menghadirkan rasa aman bagi konsumen.

\section{Keputusan Pembelian}

Keputusan pembelian yaitu menyangkut keputusan konsumen yang berhubungan dengan preferensi pada sebuah merek yang akan dijadikan sebagai pilihan. Keputusan pembelian berhubungan tetang bagaimana memahami pengambilan sebuah keputusan konsumen. Memahami tahapan keterlibatan konsumen pada suatu produk yang berarti bahwa pemasaran berusaha mengidentifikasi beberapa penyebab dari seseorang memiliki rasa keterlibatan atau tidak pada pembelian produk atau jasa (Zubaidah, 2016). Perilaku pembelian konsumen adalah perilaku pembelian akhir dari konsumen, baik individual maupun rumah tangga yang membeli barang-barang dan jasa untuk konsumsi pribadi. Menurut Kotler dan Armstrong (2012) keputusan pembelian merupakan seuah tahap dalam proses pengambilan keputusan pembeli dimana konsumen benar-benar mengambil keputusan untuk membeli (Afrian, 2017). Perilaku konsumen mempunyai berbagai dampak yang mendasari seseorang dalam mengambil keputusan pembelian pada suatu produk atau merek.

Berdasarkan pejelasan diatas keputusan pembelian adalah salah suatu tahapan dalam penyelesaian masalah yang terdiri dari tahapan analisa, penelusuran suatu informasi, penilaian terhadap beberapa sumber seleksi terhadap pilihan pembelian, dan keputusan pembelian pada suatu produk. Kotler dan Armstrong (2012) mengmukakan jenis-jenis keputusan pembelian yaitu:

1. Significant Differences Between Brands yaitu seorang pelanggan memiliki pandangan perbedaan yang signifikan diantara berbagai pilihan pada produk atau merek.

2. Few Differences Between Brands yaitu seorang pelanggan berfokus pada beberapa perbedaan merek yang signifikan.

3. Complex Buying Behavior yaitu soerang konsumen yang memiliki keterlibatan pada perilaku pembelian yang dianggpa rumit pada saat mereka sangat terlibat serta menyadari adanya perbedaan yang signifikan pada berbagai merek.

4. Dissonance Reducing Buying Behavior yaitu seorang konsumen memiliki keterlibatan pada sebuah transaksi pembelian. Keterlibatan yang tinggi didasarkan pada fakta bahwa pembelian tersebut mahal dan berisiko. 
5. Habitual Buying Behavior yaitu berhubungan dengan rendahnya daya pembelian produk akibat kondisi rendahnya keterlibatan konsumen.

6. Variety Seeking Buying Behavior yaitu berhubungan dengan situasi pembeli yang ditandai dengan adanya keterlibatan konsumen yang rendah namun perbedaan merek yang signifikan, dalam situasi ini, konsumen sering berpindah merek.

\section{METODOLOGI PENELITIAN}

Pendekatan penelitian yang digunakan yaitu pendekatan penelitian kuantitatif. Populasi merupakan keseluruhan dari objek atau subjek yang berada pada suatu wilayah serta telah memenuhi syarat yang ditetapkan yang berhubungan pada masalah penelitian, keseluruhan individu yang terdapat dalam ruang lingkup penelitian. kemudian ditarik kesimpulannya (Hamid, 2019). Populasi pada penelitian ini yaitu mahasiswa Fakultas Ekonomi Dan Bisnis Angkatan tahun 2016 berjumlah 253 Mahasiswa Di Universitas Muhammadiyah Palopo, terdiri dari manajemen sebanyak 106 siswa, akutansi sebanyak 129 siswa dan studi pembangunan sebanyak 18 siswa. Berikut adalah nama-nama jurusan fakultas ekonomi dan bisnis di Universitas Muhammdiyah Palopo yang menjadi objek penelitian.

Tabel 2. Mahasiswa Fakultas Ekonomi dan Bisnis Universitas Muhammadiyah Palopo

\begin{tabular}{|c|l|r|}
\hline No & Jurusan & Jumlah \\
\hline 1 & Manajemen & 106 \\
\hline 2 & Akutansi & 129 \\
\hline 3 & Studi Pembangunan & 18 \\
\hline & Jumlah & $\mathbf{2 5 3}$ \\
\hline
\end{tabular}

Sumber Data: Siaka Universitas Muhammadiyah Palopo 2019/2020

Sampel merupakan keseluruhan dari kelompok individu yang ditetapkan atau dipilih yang bersumber dari populasinya (Hamid, 2019). Untuk menentukan besarnya sampel, peneliti Syarifuddin (2011) menggunakan rumus Slovin sebagai berikut:

$$
n=\frac{N}{N \cdot d^{2}+1}
$$

Ket:

n: jumlah sampel

$\mathrm{N}$ : jumlah populasi

$\mathrm{d}^{2}$ : presisi (ditetapakan 5\% dengan tingkatan kepercayaan 90\%)

Dari rumus Slovin diatas, maka:

$$
\begin{aligned}
n & =\frac{253}{253 \cdot(5 \%)^{2}+1} \\
& =155
\end{aligned}
$$

Jadi, jumlah minimum responden adalah 155 . 
Tabel 3. Penentuan Sampel Penelitian

\begin{tabular}{|c|c|c|c|}
\hline No & Jurusan & \multicolumn{2}{|c|}{ Jumlah Sampel } \\
\hline 1. & Manajemen & $106 / 253 * 155$ & 64 \\
\hline 2. & Akutansi & $129 / 253 * 155$ & 79 \\
\hline 3. & Studi Pembagunan & $18 / 253 * 155$ & 12 \\
\hline & Total & $\mathbf{1 5 5}$ \\
\hline
\end{tabular}

Dengan demikian ukuran besarnya sampel untuk penelitian ini sebanyak 155 yang menjadi 155 responden.

Penelitian ini melalui teknik pengujian data yaitu uji validitas, uji reliabilitas, dan uji hipotesis dengan pendekatan analsisi regresi linier berganda. Uji regresi linear berganda bertujuan untuk mengetahui arah hubungan antara variabel independen dengan variabel dependen apakah positif atau negatif. Adapun bentuk persamaan regresi adalah: $\mathrm{Y}=\mathrm{a}+\mathrm{b} 1 \mathrm{X} 1+\mathrm{b} 2 \mathrm{X} 2+\mathrm{b} 3 \mathrm{X} 3+\mathrm{e}$

Dimana:

$$
\begin{array}{ll}
\mathrm{Y} & =\text { Keputusan pembelian } \\
\mathrm{a} & =\text { Harga Y bila } \mathrm{X}=0 \text { (harga konstan) } \\
\mathrm{b} 1-\mathrm{b} 4 & =\text { Koefisien regresi } \\
\mathrm{X} 1 & =\text { Periklanan } \\
\mathrm{X} 2 & =\text { Celebrity endorser } \\
\mathrm{X} 3 & =\text { Label Halal } \\
\mathrm{e} & =\text { Standar } \text { error }
\end{array}
$$

\begin{tabular}{|c|c|c|c|}
\hline Variabel & Defenisi & Indikator & Sumber \\
\hline \multirow{5}{*}{ Periklanan } & \multirow{5}{*}{$\begin{array}{l}\text { Periklanan adalah suatu alat } \\
\text { untuk mempromosikan atau } \\
\text { menginformasikan produk } \\
\text { shampo sunsilk hijab pada } \\
\text { konsumen }\end{array}$} & Daya Tarik Pesan & \multirow{5}{*}{$\begin{array}{l}\text { Kotler dan } \\
\text { Keller (2009); } \\
\text { Lutviansah } \\
\text { (2016) }\end{array}$} \\
\hline & & Janji Rasional Produk & \\
\hline & & $\begin{array}{l}\text { Janji Pengalaman yang } \\
\text { akan diterima }\end{array}$ & \\
\hline & & Teknik Suara & \\
\hline & & Ekspresi dan bahasa & \\
\hline \multirow{2}{*}{$\begin{array}{l}\text { Label } \\
\text { Halal }\end{array}$} & \multirow{2}{*}{$\begin{array}{lr}\text { Cara konsumen } & \text { untuk } \\
\text { mengetahui kehalalan } & \text { suatau } \\
\text { produk shampo yang } & \text { sesuai } \\
\text { syariat agama Islam } & \end{array}$} & $\begin{array}{lr}\text { Label Halal yang ada pada } \\
\text { produk } & \text { shampoo } \\
\text { menjamin } & \text { kehalalan } \\
\text { produk } & \\
\end{array}$ & \multirow{2}{*}{$\begin{array}{l}\text { Khuwaroh, } \\
\text { Widarko, dan } \\
\text { ABS. (2019); } \\
\text { Iuddin (2018) }\end{array}$} \\
\hline & & $\begin{array}{l}\text { Label halal yang terdapat } \\
\text { pada produk shampoo } \\
\text { mampu mengalahkan } \\
\text { pesaing dari produk lain }\end{array}$ & \\
\hline
\end{tabular}

Berikut disajikan defenisi dan indikator untuk setiap variabel yang digunakan pada penelitian ini.

Tabel 4. Defenisi dan Indikator Variabel Penelitian 


\begin{tabular}{|c|c|c|c|}
\hline & & $\begin{array}{l}\text { Label halal yang dimiliki } \\
\text { adalah bersifat resmi dari } \\
\text { LPPOM-MUI }\end{array}$ & \\
\hline & & $\begin{array}{l}\text { Proses pembuatan suatu } \\
\text { produk dilakkan dalam } \\
\text { pengawasan LPPOM- } \\
\text { MUI } \\
\end{array}$ & \\
\hline & & $\begin{array}{llr}\text { Bentuk } & \text { lain } & \text { yang } \\
\text { disertakan } & \text { pada } & \text { pangan } \\
\text { yang } & \text { menyebutkan } \\
\text { kehalalan produk } & \\
\text { kehal }\end{array}$ & \\
\hline \multirow{5}{*}{$\begin{array}{l}\text { Celebrity } \\
\text { Endorser }\end{array}$} & \multirow{5}{*}{$\begin{array}{l}\text { Salah satu cara perusahaan } \\
\text { dimana cara ini yang lagi masa } \\
\text { kini untuk menunjukkan, } \\
\text { menyampaikan pesan atau } \\
\text { mengajurkan mahasiswa untuk } \\
\text { membeli produk shampo } \\
\text { tersebut }\end{array}$} & Crediability & \multirow{5}{*}{$\begin{array}{c}\text { Salim dan } \\
\text { Bachri (2014) }\end{array}$} \\
\hline & & Likeability & \\
\hline & & Attractiveness & \\
\hline & & Meaningfulness & \\
\hline & & $\begin{array}{l}\text { Trustworthinessof } \\
\text { Endorser }\end{array}$ & \\
\hline \multirow{5}{*}{$\begin{array}{l}\text { Keputusan } \\
\text { Pembelian }\end{array}$} & \multirow{5}{*}{$\begin{array}{l}\text { Keputusan pembelian konsumen } \\
\text { akhir perorangan dan rumah } \\
\text { tangga yang melakukan } \\
\text { transaksi pembelian barang dan } \\
\text { jasa untuk kebutuhan konsumsi } \\
\text { pribadi }\end{array}$} & $\begin{array}{lr}\text { ketertarikan } & \text { untuk } \\
\text { menggunakan } & \text { produk } \\
\text { shampoo karena } & \text { sudah } \\
\text { berlabel halal } & \\
\end{array}$ & \multirow{5}{*}{$\begin{array}{l}\text { Salim dan } \\
\text { Bachri (2014); } \\
\text { Khuwaroh, } \\
\text { Widarko, dan } \\
\text { ABS. (2019) }\end{array}$} \\
\hline & & $\begin{array}{l}\text { Keinginan untuk mencoba } \\
\text { produk }\end{array}$ & \\
\hline & & $\begin{array}{l}\text { Kualitas produk yang } \\
\text { ditawarkan }\end{array}$ & \\
\hline & & $\begin{array}{l}\text { Adopsi/terbiasa } \\
\text { menggunakan (pernah } \\
\text { memiliki) }\end{array}$ & \\
\hline & & $\begin{array}{l}\text { Kesadaran akan } \\
\text { kebutuhan }\end{array}$ & \\
\hline
\end{tabular}

\section{HASIL PENELITIAN}

\section{Analisis Statistik Deskriptif}

Dalam penelitian ini, instrumen penelitian yang digunakan adalah kuesioner (angket)dengan skala likert. Menurut (Sugiyono, 2012) "skala likert digunakan untuk mengukur sikap, pendapat dan pandangan mahasiswa atau sekelompok siswa tentang fenomena yang terjadi". Pernyataan yang dijawab oleh responden dinilai konsisten dengan jawaban alternatif yang relevan. Ada 5 alternatif jawaban untuk kriteria evaluasi pernyataan. Yaitu untuk pernyataan positif dengan nilai $\mathrm{SS}=5, \mathrm{~S}=4, \mathrm{KS}=3$, $\mathrm{TS}=2$, dan $\mathrm{STS}=1$. Pernyataan negativenilainya adalah $\mathrm{SS}=1, \mathrm{~S}=2, \mathrm{KS}=3, \mathrm{TS}=4$, dan $\mathrm{STS}=5$. Berikut sajian data rentang skala pada model likert. 
Tabel 5. Analisis Statistik Deskriptif Instrumen Penelitian Variabel Periklanan

\begin{tabular}{|c|c|c|c|c|c|c|c|c|c|c|}
\hline \multirow[t]{2}{*}{ NO } & \multirow{2}{*}{$\begin{array}{l}\text { Variabel } \\
\text { /Indikator } \\
\text { Periklanan } \\
\text { (X1) }\end{array}$} & \multicolumn{2}{|c|}{ SS } & \multicolumn{2}{|c|}{$S$} & \multicolumn{2}{|c|}{ RR } & \multicolumn{2}{|c|}{ TS } & \multirow[b]{2}{*}{ Total } \\
\hline & & Jmlh & $(\%)$ & Jmlh & $(\%)$ & Jmlh & $(\%)$ & Jmlh & $(\%)$ & \\
\hline 1 & X1.1 & 56 & $36,1 \%$ & 61 & $39,4 \%$ & 8 & $5,2 \%$ & 0 & $0 \%$ & 155 \\
\hline 2 & $\mathrm{X} 1.2$ & 61 & $39,4 \%$ & 86 & $55,5 \%$ & 8 & $5,2 \%$ & 0 & $0 \%$ & 155 \\
\hline 3 & $\mathrm{X} 1.3$ & 66 & $39,4 \%$ & 82 & $52,9 \%$ & 7 & $4,5 \%$ & 0 & $0 \%$ & 155 \\
\hline 4 & $\mathrm{X} 1.4$ & 69 & $44,5 \%$ & 70 & $45,2 \%$ & 15 & $9,7 \%$ & 1 & $6 \%$ & 155 \\
\hline 5 & $\mathrm{X} 1.5$ & 70 & $45,2 \%$ & 83 & $53,5 \%$ & 2 & $1,3 \%$ & 0 & $0 \%$ & 155 \\
\hline
\end{tabular}

Berdasarkan table 5 deskriptif responden pada variabel periklanan di atas terdapat 155 reponden yang memberikan pernyataan bahwa item X1.1 yang menjawab sangat setuju sebanyak 56 responden, setuju sebanyak 61 responden, ragu sebanyak 8 responden, tidak setuju sebanyak 0 dan sangat tidak setuju sebanyak 0 . Untuk item X1.2 yang menjawab sangat setuju sebanyak 61 responden, setuju sebanyak 86 responden, ragu sebanyak 8 responden tidak setuju sebanyak 0 dan sangat tidak setuju sebanyak 0 . Item X1.3 yang menjawab sangat setuju sebanyak 66 responden, setuju sebanyak 82 responden, ragu - ragu sebanyak 7 responden tidak setuju sebanyak 0 dan sangat tidak setuju sebanyak 0. Item X1.4 yang menjawab sangat setuju sebanyak 69 responden, setuju sebanyak 70 responden, ragu - ragu sebanyak 15 responden, tidak setuju sebanyak 1 responden dan sangat tidak setuju sebanyak 0. Item X1.5 yang menjawab sangat setuju sebanyak 70 responden, setuju sebanyak 83 responden, ragu - ragu sebanyak 2 responden, tidak setuju sebanyak 0 dan sangat tidak setuju sebanyak 0 .

Berdasarkan table 5 bahwa untuk variabel periklanan dari kelima indikator pernataan yaitu X1.1, X1.2, X1.3, X1.4, X1.5, secara umum hasil penyebaran kuesioner pada variabel periklanan terhadap mahasiswa universitas muhammadiyah palopo di nilai yang paling tertinggi yaitu X1.2 atau pernyataan setuju adalah sebanyak 86 responden di banding dari pernyataan yang lain. Sedangkan nilai yang paling terendah adalah X1.4 atau pernyataan tidak setuju adalah sebanyak 1 respondendengan demikian mahasiswa universitas muhammadiyah palopo sependapat dengan informasi periklanan shamposunsilk yang diberikan.

Tabel 5. Analisis Statistik Deskriptif Instrumen Variabel Celebrity Endorser

\begin{tabular}{|c|l|l|l|l|l|l|l|l|l|l|}
\hline NO & $\begin{array}{c}\text { Variabel } \\
\text { /Indikator }\end{array}$ & \multicolumn{2}{|c|}{ SS } & \multicolumn{2}{|c|}{ S } & \multicolumn{2}{c|}{ RR } & \multicolumn{2}{c|}{ TS } & \multirow{2}{*}{ Total } \\
\cline { 2 - 12 } & $\begin{array}{c}\text { Celebrity } \\
\text { Endorser } \\
(\mathrm{X} 2)\end{array}$ & Jmlah & $(\%)$ & Jmlah & $(\%)$ & Jmlah & $(\%)$ & Jmlah & $(\%)$ & \\
\hline 1 & X2.6 & 51 & $32,9 \%$ & 85 & $54,8 \%$ & 19 & $12,3 \%$ & 0 & $0 \%$ & 155 \\
\hline 2 & X2.7 & 56 & $36,1 \%$ & 89 & $57,4 \%$ & 10 & $6,5 \%$ & 0 & $0 \%$ & 155 \\
\hline 3 & X2.8 & 70 & $45,8 \%$ & 81 & $52,3 \%$ & 8 & $5,2 \%$ & 0 & $0 \%$ & 155 \\
\hline 4 & X2.9 & 41 & $25,9 \%$ & 81 & $52,3 \%$ & 33 & $21,3 \%$ & 0 & $0 \%$ & 155 \\
\hline 5 & X2.10 & 53 & $34,2 \%$ & 98 & $63,2 \%$ & 4 & $2,6 \%$ & 0 & $0 \%$ & 155 \\
\hline
\end{tabular}

Berdasarkan Tabel 6 hasil deskriptif responden pada variabel celebrity endorser di atas terdapat 155 reponden yang memberikan pernyataan bahwa item X2.6 yang menjawab sangat setuju sebanyak 51 responden, setuju sebanyak 85 responden, ragu - ragu sebanyak 19 responden tidak setuju sebanyak 0 dan sangat tidak setuju sebanyak 0 . Untuk item X2.7 yang menjawab sangat setuju sebanyak 56 responden, setuju sebanyak 89 
responden, ragu - ragu sebanyak 10 responden tidak setuju sebanyak 0 dan sangat tidak setuju sebanyak 0. Item X2.8 yang menjawab sangat setuju sebanyak 70 responden, setuju sebanyak 77 responden, ragu - ragu sebanyak 8 responden tidak setuju sebanyak 0 dan sangat tidak setuju sebanyak 0. Item X2.9 yang menjawab sangat setuju sebanyak 40 responden, setuju sebanyak 81 responden, ragu - ragu sebanyak 34 responden, tidak setuju sebanyak 0 responden. Item X2.10 terdapat 53 responden yang memberikan jawaban sangat setuju, sebanyak 98 responden memberikan jawaban setuju, sebanyaj 4 responden yang menjawab ragu-ragu, serta masing -masing 0 yang memberikan jawaban tidak setuju dan sangat tidak setuju.

Berdasarkan tabel 6 bahwa untuk variabel celebrity endorser dari kelima indikator pernyataan yaitu X2.6, X2.7, X2.8, X2.9, X2.10, secara umum hasil penyebaran kuesioner pada variabel celebrity endorser terhadap mahasiswa universitas muhammadiyah palopo di nilai yang paling tertinggi yaitu X2.6 atau pernyataan setuju adalah sebanyak 85 responden di banding dari pernyataan yang lain. Sedangkan nilai yang paling terendah adalah X2.10 atau pernyataan tidak setuju adalah sebanyak 2 responden. Dengan demikian mahaiswa universitas muhammadiyah palopo sependapat dengan celebrity endorser shampoo sunsilk yang diberikan

Tabel 7. Analisis Statistik Deskriptif Instrumen Variabel Label Halal

\begin{tabular}{|c|l|l|c|c|c|c|c|c|c|c|}
\hline NO & $\begin{array}{l}\text { Variabel } \\
\text { /Indikator }\end{array}$ & \multicolumn{2}{|c|}{ SS } & \multicolumn{2}{c|}{ S } & \multicolumn{2}{c|}{ RR } & \multicolumn{2}{c|}{ STS } & Total \\
\cline { 2 - 13 } & $\begin{array}{l}\text { Label Halal } \\
\text { (X3) }\end{array}$ & Jmlah & $(\%)$ & Jmlah & $(\%)$ & Jmlah & $(\%)$ & Jmlah & $(\%)$ & \\
\hline 1 & X3.11 & 67 & $43,2 \%$ & 85 & $54,8 \%$ & 3 & $1,9 \%$ & 0 & $0 \%$ & 155 \\
\hline 2 & X3.12 & 74 & $47,1 \%$ & 79 & $51,0 \%$ & 2 & $1,3 \%$ & 0 & $0 \%$ & 155 \\
\hline 3 & X3.13 & 76 & $49,0 \%$ & 76 & $49,0 \%$ & 3 & $1,9 \%$ & 0 & $0 \%$ & 155 \\
\hline 4 & X3.14 & 80 & $51,6 \%$ & 66 & $42,6 \%$ & 9 & $5,8 \%$ & 0 & $0 \%$ & 155 \\
\hline 5 & X3.15 & 74 & $47,7 \%$ & 76 & $49,0 \%$ & 4 & $2,6 \%$ & 1 & $6 \%$ & 155 \\
\hline
\end{tabular}

Berdasarkan hasil deskriptif responden pada variabel label halal di atas terdapat 155 reponden yang memberikan pernyataan bahwa item X3.11 yang menjawab sangat setuju sebanyak 53 responden, setuju sebanyak 98 responden, ragu - ragu sebanyak 4 responden tidak setuju sebanyak 0 dan sangat tidak setuju sebanyak 0. Untuk item X3.12 yang menjawab sangat setuju sebanyak 74 responden, setuju sebanyak 79 responden, ragu ragu sebanyak 2 responden tidak setuju sebanyak 0 dan sangat tidak setuju sebanyak. Item X3.13 yang menjawab sangat setuju sebanyak 76 responden, setuju sebanyak 76 responden, ragu - ragu sebanyak 3 responden tidak setuju sebanyak 0 dan sangat tidak setuju sebanyak 0. Item X3.14 yang menjawab sangat setuju sebanyak 80 responden, setuju sebanyak 66 responden, ragu - ragu sebanyak 9 responden tidak setuju sebanyak 0 dan sangat tidak setuju sebanyak 0 responden. Item X3.15 yang menjawab sangat setuju sebanyak 74 responden, setuju sebanyak 76 responden, ragu - ragu sebanyak 4 responden, tidak setuju sebanyak 0 responden sangat tidak setuju sebanyak 1 responden.

Berdasarkan tabel 7 bahwa untuk variabel label halal dari kelima indikator pernyataan yaitu X3.11, X3.12, X3.13, X3.14, X3.15, secara umum hasil penyebaran kuesioner pada variabel label halal terhadap mahaiswa universitas muhammadiyah palopo di nilai yang paling tertinggi yaitu X3.11 atau pernyataan setuju adalah sebanyak 85 responden di banding dari pernyataan yang lain. Sedangkan nilai yang paling terendah adalah X3.15 atau pernyataan tidak setuju adalah sebanyak 1 responden. Dengan 
demikian mahasiswa universitas muhammadiyah palopo sependapat dengan informasi label halal shampo sunsilk yang diberikan.

Tabel 8. Analisis Statistik Deskriptif Instrumen Variabel Keputusan Pembelian

\begin{tabular}{|c|c|c|c|c|c|c|c|c|c|c|}
\hline \multirow[t]{2}{*}{$\mathrm{NO}$} & \multirow{2}{*}{$\begin{array}{c}\text { Variabel } \\
\text { /Indikator } \\
\text { Keputusan } \\
\text { Pembelian( } \\
\text { Y) }\end{array}$} & \multicolumn{2}{|c|}{$\mathrm{SS}$} & \multicolumn{2}{|c|}{ S } & \multicolumn{2}{|c|}{ RR } & \multicolumn{2}{|c|}{$\mathrm{TS}$} & \multirow[b]{2}{*}{ Total } \\
\hline & & Jmlah & $(\%)$ & Jmlah & $(\%)$ & jmlah & $(\%)$ & Jmlah & $(\%)$ & \\
\hline 1 & Y.1 & 52 & $33,5 \%$ & 92 & $59,4 \%$ & 9 & $5,8 \%$ & 2 & $1,3 \%$ & 155 \\
\hline 2 & Y.2 & 59 & $38,1 \%$ & 85 & $54,8 \%$ & 10 & $6,5 \%$ & 1 & $6 \%$ & 155 \\
\hline 3 & Y.3 & 58 & $37,4 \%$ & 83 & $53,5 \%$ & 13 & $8,4 \%$ & 1 & $6 \%$ & 155 \\
\hline 4 & Y.4 & 63 & $40,6 \%$ & 81 & $52,3 \%$ & 8 & $5,2 \%$ & 3 & $1,9 \%$ & 155 \\
\hline 5 & Y.5 & 76 & $48,4 \%$ & 71 & $45,8 \%$ & 6 & $3,9 \%$ & 2 & $1,3 \%$ & 155 \\
\hline
\end{tabular}

Berdasarkan table 8 hasil deskriptif responden pada variabel keputusan pembeliandi atas terdapat 155 reponden yang memberikan pernyataan bahwa item Y.1 yang menjawab sangat setuju sebanyak 52 responden, setuju sebanyak 92 responden, ragu - ragu sebanyak 9 responden, , tidak setuju sebanyak 1 responden sangat tidak setuju sebanyak 0 responden.Untuk item Y.2 yang menjawab sangat setuju sebanyak 59 responden, setuju sebanyak 85 responden, ragu - ragu sebanyak 10 responden, tidak setuju sebanyak 1 responden, dan sangat tidak setuju sebanyak 0 responden. Item Y.3 yang menjawab sangat setuju sebanyak 58 responden, setuju sebanyak 83 responden, ragu - ragu sebanyak 13 responden dan tidak setuju sebanyak 1 responden dan sangat tidak setuju sebanyak 0 responden. Item Y.4 yang menjawab sangat setuju sebanyak 63 responden, setuju sebanyak 81 responden, ragu - ragu sebanyak 8 responden dan tidak setuju sebanyak 3 responden. Item Y.5 yang menjawab sangat setuju sebanyak 76 responden, setuju sebanyak 71 responden, ragu - ragu sebanyak 6 responden, dan tidak setuju sebanyak 2 responden sangat tidak setuju sebanyak 0 responden.

Berdasarkan tabel 8 bahwa untuk variabel keputusan pembelian konsumen dari kelima indikator pernyataan yaitu Y.1, Y2, Y.3, Y.4, Y.5, secara umum hasil penyebaran kuesioner terhadap mahasiswa universitas muhammadiyah palopo di nilai yang paling tertinggi yaitu Y.1 atau pernyataan setuju adalah sebanyak 92 responden di banding dari pernyataan yang lain. Sedangkan nilai yang paling terendah adalah Y.3 atau pernyataan tidak setuju adalah sebanyak 1 responden. Dengan demikian mahaiswa universitas muhammadiyah palopo sependapat dengan infrmasi keputusan pembelian konsumen shampo sunsilk yang diberikan.

\section{Uji validitas dan reliabilitas}

Adapun hasil pengujian validitas dan reliabilitas untuk variabel yang digunakan dalam penelitian ini yaitu sebagai berikut:

Tabel 9. Hasil Uji Validitas dan Reliabilitas Periklanan

\begin{tabular}{|c|c|c|c|c|c|c|}
\hline Variabel & Item & r hitung & r table & $\begin{array}{c}\text { Cronbach's Alpha } \\
\text { Based on Standardized } \\
\text { Items }\end{array}$ & \multicolumn{2}{|c|}{ Keterangan } \\
\hline \multirow{3}{*}{ Periklanan } & $\mathrm{X} 1.1$ & 0,690 & 0,157 & 0,803 & Valid & Reliabel \\
\cline { 2 - 7 } & $\mathrm{X} 1.2$ & 0,761 & 0,157 & 0,803 & Valid & Reliabel \\
\cline { 2 - 7 } & 0,826 & 0,157 & 0,803 & Valid & Reliabel \\
\hline
\end{tabular}




\begin{tabular}{|c|c|c|c|c|c|c|}
\hline & X1.4 & 0,812 & 0,157 & 0,803 & Valid & Reliabel \\
\cline { 2 - 7 } & X1.5 & 0,642 & 0,157 & 0,803 & Valid & Reliabel \\
\cline { 2 - 7 } & X1.5 & 0,642 & 0,157 & 0,803 & Valid & Reliabel \\
\hline
\end{tabular}

Berdasarkan Tabel 9 diatas semua item pernyataan mengenai peeriklanan dalam instrumen penelitian dinyatakan valid karena $r$ hitung $>r$ tabel 0,157. Dan hasil uji reliabilitas variabel periklanan dapat disimpulkan bahwa semua item pernyataan reliabel karena nilai dari cronbach's alpha variabel periklanan yaitu 0,803>0,60

Tabel 10. Hasil Uji Validitas dan Reliabilitas Celebrity Endorser

\begin{tabular}{|c|c|c|c|c|c|c|}
\hline Variabel & Item & r hitung & $\mathrm{r}$ table & $\begin{array}{c}\text { Cronbach's Alpha } \\
\text { Based on } \\
\text { Standardized Items }\end{array}$ & \multicolumn{2}{|c|}{ Keterangan } \\
\hline \multirow{4}{*}{$\begin{array}{c}\text { Celebrity } \\
\text { endorser }\end{array}$} & $\mathrm{X} 2.6$ & 0,393 & 0,157 & 0,139 & Valid & Reliabel \\
\cline { 2 - 7 } & $\mathrm{X} 2.7$ & 0,367 & 0,157 & 0,139 & Valid & Reliabel \\
\cline { 2 - 7 } & $\mathrm{X} 2.8$ & 0,266 & 0,157 & 0,139 & Valid & Reliabel \\
\cline { 2 - 7 } & $\mathrm{X} 2.10$ & 0,384 & 0,157 & 0,139 & Valid & Reliabel \\
\hline
\end{tabular}

Berdasarkan Tabel 10 diatas semua item pernyataan mengenai celebrity endorser dalam instrumen penelitian dinyatakan valid karena $r$ hitung $>r$ tabel 0,157. Dan hasil uji reliabilitas variabel label halal dapat disimpulkan bahwa semua item pernyataan reliabel karena nilai dari cronbach's alpha variabel celebrity endorser yaitu 0,139>0,60.

Tabel 11. Hasil Uji Validitas dan Reliabilitas Label Halal

\begin{tabular}{|c|c|c|c|c|c|c|}
\hline Variabel & Item & r hitung & r tabel & $\begin{array}{c}\text { Cronbach's Alpha } \\
\text { Based on } \\
\text { Standardized } \\
\text { Items }\end{array}$ & \multicolumn{2}{|c|}{ Keterangan } \\
\hline \multirow{5}{*}{ Label Halal } & X3.11 & 0,700 & 0,157 & 0,823 & Valid & Reliabel \\
\cline { 2 - 7 } & X3.12 & 0,791 & 0,157 & 0,823 & Valid & Reliabel \\
\cline { 2 - 8 } & X3.13 & 0,818 & 0,157 & 0,823 & Valid & Reliabel \\
\cline { 2 - 7 } & X3.14 & 0,811 & 0,157 & 0,823 & Valid & Reliabel \\
\cline { 2 - 7 } & X3.15 & 0,689 & 0,157 & 0,823 & Valid & Reliabel \\
\hline
\end{tabular}

Berdasarkan Tabel 11 diatas semua item pernyataan mengenai label halal dalam instrumen penelitian dinyatakan valid karena $r$ hitung $>r$ tabel 0,157. Dan hasil uji reliabilitas variabel label halal dapat disimpulkan bahwa semua item pernyataan reliabel karena nilai dari cronbach's alpha variabel label halal yaitu 0,823>0,60.

Tabel 12. Hasil Uji Validitas dan Reliabilitas Keputusan Pembelian Konsumen

\begin{tabular}{|c|c|c|c|c|c|c|}
\hline Variabel & Item & r hitung & $\mathrm{r}$ table & $\begin{array}{c}\text { Cronbach's Alpha } \\
\text { Based on Standardized } \\
\text { Items }\end{array}$ & \multicolumn{2}{|c|}{ Keterangan } \\
\hline & Y.1 & 0,813 & 0,157 & 0,885 & Valid & Reliabel \\
\cline { 2 - 7 } & Y.2 & 0,882 & 0,157 & 0,885 & Valid & Reliabel \\
\cline { 2 - 7 } Keputusan & Y.3 & 0,776 & 0,157 & 0,885 & Valid & Reliabel \\
\cline { 2 - 7 } $\begin{array}{l}\text { Pembelian } \\
\text { Konsumen }\end{array}$ & Y.4 & 0,776 & 0,157 & 0,885 & Valid & Reliabel \\
\cline { 2 - 7 } & Y.5 & 0,778 & 0,157 & 0,885 & Valid & Reliabel \\
\hline
\end{tabular}


Berdasarkan Tabel 12 diatas semua item pernyataan mengenai keputusan pembelian konsumen dalam instrumen penelitian dinyatakan valid karena $r$ hitung $>r$ tabel 0,157. Dan hasil uji reliabilitas variabel keputusan pembelian konsumen dapat disimpulkan bahwa semua item pernyataan reliabel karena nilai dari cronbach's alpha variabel keputusan pembelian konsumen yaitu 0,885 > 0,60.

\section{Hasil Analisis Regresi Linear Berganda}

Analisis regresi linear berganda digunakan dalam penelitian ini dengan tujuan untuk membuktikan hipotesis mengenai adanya pengaruh variabel periklanan celebrity endorser dan label halal pada keputusan pembelian. Adapun hasil perhitungan regresi linear berganda dapat tersaji pada tabel 13 sebagai berikut:

Tabel 13. Regresi Linear Berganda

\begin{tabular}{|c|c|c|c|c|c|}
\hline \multicolumn{6}{|c|}{ Coefficients $^{a}$} \\
\hline \multirow[b]{2}{*}{ Model } & \multicolumn{2}{|c|}{$\begin{array}{c}\text { Unstandardized } \\
\text { Coefficients }\end{array}$} & \multirow{2}{*}{$\begin{array}{c}\text { Standardized } \\
\text { Coefficients } \\
\text { Beta }\end{array}$} & \multirow[b]{2}{*}{$T$} & \multirow[b]{2}{*}{ Sig. } \\
\hline & $B$ & Std. Error & & & \\
\hline $1 \quad$ (Constant) & 5.403 & 2,680 & & 2,016 &, 046 \\
\hline Periklanan $\left(\mathrm{X}_{1}\right)$ & ,444 & ,088, & ,368 & 5,019 &, 000 \\
\hline Celebrity endorser $\left(\mathrm{X}_{2}\right)$ & 146 & ,053 & 200 & 2,765 &, 006 \\
\hline Label halal &, 149 & ,087 & 125 & 1,705 & ,090 \\
\hline
\end{tabular}

Tabel 13 menunjukkan perhitungan regresi linear berganda, nilai konstanta yang diperoleh adalah 5,403 sedangkan koefisien regresi linear berganda periklanan adalah 0,444, koefisien regresi linear berganda celebrity endorser adalah 0,146 dan koefisien regresi linear berganda label halal adalah 0,149. Sehingga persamaan regresi yang diperoleh adalah sebagai berikut:

$\mathrm{Y}=$ Kinerja Karyawan

$$
\mathrm{Y}=5.403+0,444 \mathrm{X}_{1}+0,146 \mathrm{X}_{2}+0,149 \mathrm{X}_{3}
$$

$\mathrm{X}_{1}=$ Periklanan

$\mathrm{X}_{2}=$ Celebrity Endorser

$\mathrm{X}_{3}=$ Label Halal

\section{Uji hipotesis}

\section{Secara parsial (uji t)}

Pengaruh periklanan terhadap keputusan pembelian berpengaruh positif signifikan dengan nilai probabilitas sebesar 0,000 lebih kecil dari level of significance $(\alpha$ $=0,05)$. Selanjutnya pengaruh celebrity endorserterhadap keputusan pembelian berpengaruh positif signifikan dengan nilai probabilitas sebesar 0,006 lebih kecil dari level of significance $(\alpha=0,05)$. Sedangakan untuk pengaruh label halal terhadap keputusan pembelian berpengaruh positif tidak signifikan dengan probabilitas sebesar 0,090 lebih besar dari level of signifikan $(\alpha=0,05)$.

\section{Secara simultan (uji F)}

Pengujian pengaruh variabel independen (periklanan, celebrity endorser dan label halal) terhadap variabel dependen (keputusan pembelian konsumen) secara simultan 
dengan menggunakan uji $\mathrm{F}$ yaitu membandingkan antara probabilitas Fhitung dengan level signifikan $(\alpha=5 \%)$.

$$
\text { Tabel 14. Hasil Uji F }
$$

ANOVA ${ }^{a}$

\begin{tabular}{l|r|r|r|r|r} 
Model & Sum of Squares & Df & Mean Square & \multicolumn{1}{c}{$F$} & \multicolumn{1}{c}{ Sig. } \\
\hline $\begin{array}{l}\text { Regression } \\
\text { Residual }\end{array}$ & 234.533 & 3 & 78.178 & 14.084 & ,000 $^{\mathrm{b}}$ \\
\hline \multicolumn{1}{l|}{ Total } & 838.176 & 151 & 5.551 & & \\
\hline
\end{tabular}

Dari hasil Tabel 14 diatas diperoleh nilai sig. sebesar 0,000. < 0,05 atau F hitung 14,084 $>\mathrm{F}$ tabel sebesar 0,10. Artinya adalah periklanan, celebrity endorser dan label halal berpengaruh secara simultan dan signifikan terhadap keputusan pembelian.

\section{Koefisien determinasi $\left(\mathbf{R}^{2}\right)$}

Uji koefisien determinasi ini digunakan untuk mengukur seberapa jauhvariabelvariabel bebas dalam menerangkan variabel terikatnya. Nilai koefisien determinasi untuk dua variabel bebas ditentukan dengan nilai:

\section{Tabel 15. Hasil Koefisien Determinasi $\left(\mathbf{R}^{2}\right)$}

\begin{tabular}{ll|r|r|r} 
& & \multicolumn{3}{c}{ Model Summary } \\
Model & $R$ & $R$ Square & Adjusted R Square & Std. Error of the Estimate \\
\hline 1 &, $468^{\mathrm{a}}$ &, 219 &, 203 & 2,356 \\
\hline
\end{tabular}

Berdasakan Tabel 15 hasil koefisien determinasi $\left(\mathrm{R}^{2}\right)$ diatas, diperoleh nilai adjusted $R$ square sebesar 0,219. Artinya besaran variasi perubahan keputusan pembelian pada mahasiswa universitas muhammadiyah palopo dapat dipengaruhi oleh variabel periklanan,celebrity endorser dan label halal sebesar 21,9\%. Sedangkan sisanya sebesar $78,1 \%$ dipengaruhi oleh variabel lain yang tidak di terdapat dalam model penelitian ini.

\section{PEMBAHASAN}

\section{Pengaruh Periklanan terhadap Keputusan Pembelian Produk Shampo Sunsilk} Hijab

Untuk pengaruh periklanan terhadap keputusan pembelian produk shampo sunsilk hijab dengan hasil uji regresi menunjukkan bahwa variabel periklanan berpengaruhpostif dan signifikan $(0,000<0,05)$ terhadap keputusan pembelian produk shampo sunsilk hijab dengan koefisien 0,444 . Hal ini berarti semakin meningkatnya periklanan yang dilakukan responden maka akan semakin tinggi keputusan pembelian produk shampo. Hasil ini mendukung pendapat (Seyathadi, 2012), keberadaan Periklanan pada suatuproduk sangatlah penting. Hal ini dikarenakan periklanan merupakan perkenalan sebuah produk. Dengan adanya periklanan, konsumen bisa membedakan antara produk satu dengan yang lainnya. Selain itu, konsumen juga dapat memperoleh produk sesuai dengan yang diinginkannya. Penelitian ini sejalan dengan hasil penelitian (Premi Wahyu Widyiningrum, 2017), Periklanan berpengaruh signifikan terhadap keputusan pembelian 
dan celebrity endorser berpengaruh signifikan terhadap keputusan pembelian. Temuan penelitian ini tentunya memberikan informasi bahwa daya tarik iklan, janji rasional produk pada iklan, janji terhadap pengalaman yang akan diterima, teknik suara serta ekspresi bahasa yang digunakan pada iklan ternyata mampu mempengaruhi keputusuan konsumen untuk memilih produk shampoo sunsilk hijab.

\section{Pengaruh Celebrity Endorser terhadap Keputusan Pembelian Produk Shampoo Sunsilk Hijab}

Untuk pengaruh celebrity endorser terhadap keputusan pembelian produk shampoo sunsilk dengan hasil uji regresi menujukkan bahwa variabel celebiry endorser berpengaruh secara signifikan $(0,006<0,05)$ terhadap keputusan pembelian produk shampo sunsilk hijab. Hal ini berarti bahwa peran selebrity endorser mampu dipersepsikan dengan baik oleh responden dalam hal keputusan mereka untuk memilih produk shampo sunsilk hijab. Hasil temuan ini sejalan dengan penelitian Mentari (2018) yang menyimpulkan bahwa variabel celebrity endorser berpengaruh signifikan terhadap keputusan pembelian. Temuan penelitian ini tentunya memberikan informasi bahwa kredibilitas iklan, kesukaan dan daya tarik pada celebrity endorser pada iklan ternyata mampu mempengaruhi keputusuan konsumen untuk memilih produk shampoo sunsilk hijab.

\section{Pengaruh Label Halal terhadap Keputusan Pembelian Produk Shampo Sunsilk Hijab}

Untuk pengaruh label halal terhadap keputusan pembelian produk shampo sunsik hijab. Hasil uji regresi menunjukkan bahwa variabel label halal berpengaruh postif namun tidak signifikan $(0,090>0,05)$ terhadap keputusan pembelian produk shampo dengan koefisien 0,149. Hal ini memberikan informasi bahwa label halal pada shampo sunsilk hijab bukan merupakan hal yang perioritas yang diutamakan oleh responden. Hasil temuan dalam penelitian ini mendukung hasil temuan penelitian sebalumnya yang dilakukan oleh (Khuwaroh, 2018) bahwa label halal tidak berpengaruh signifikan terhadap keputusan pembelian. Temuan penelitian ini tentunya memberikan informasi bahwa label halal yang tertera pada produk bukan merupakan indikator yang diperhatikan oleh responden dalam memilih produk shampoo sunsilk hijab. Selain itu label halal bukanlah indikator yang digunakan untuk memberikan garansi jaminan pada produk untuk bisa bersaing dengan produk lain. Selain itu label halal yang dimiliki bersifat resmi dari LPPOM-MUI juga bukan merupakan indikator yang dapat mempengaruhi keputusan konsumen dalam memilih produk. Kondisi ini tentunya tidak terlepas pada responden yang digunakan pada penelitian ini yaitu mahasiswa strata satu perguruan tinggi Universitas Muhammadiyah Palopo. Karakter berdasarkan latar belakang tingkat usia yang masih muda adalah salah satu indikator utama yang mempengaruhi mereka dalam memutuskan untuk memilih sebuah produk. Usia merupakan element utama yang berpengaruh terhadap niat beli konsumen (Mahendra dan Ardani, 2015).

\section{KESIMPULAN}

Berdasarkan hasil analisis statistik yang telah diuraikan sebelumnya dapat diambil beberapa kesimpulan diantaranya yaitu pertama, periklanan berpengaruh positif dan signifikan terhadap keputusan pembelian produk shampo sunsilk hijab. Kedua, untuk celebrity endorser berpengaruh signifikan terhadap keputusan pembelian produk shampo sunsilk hijab, dan untuk label halal berpengaruh tidak signifikan terhadap keputusan 
pembelian produk shampo sunsilk hijab. Selanjutnya secara simultan bahwa periklanan, celebrity endorser dan label halal berpengaruh signifikan terhadap keputusan pembelian produk shampo sunsilk hijab.

\section{DAFTAR PUSTAKA}

Afrian (2017) Pengaruh Daya Tarik Iklan, Citra Merek, Kemasan Produk, Label Halal Dan Harga Terhadap Keputusan Pembelian Mie Instan Indomie di Jurnal Administrasi Bisnis Uin Raden Fatah Palembang European Scientific, 1 (3) 1-10. https://doi.org/10.1037/0022-3514.51.6.1173

Andrianto (2016). Pengaruh Celebrity Endorser dan Brand Image pada Proses Keputusan Pembelian. Management Analysis Journal, 5(2), 104-109. https://doi.org/10.15294/maj.v5i2.8055

Bearden \& Ingram (2007).Marketing Managemen:Knowledge and Skills,Internasional Edition McGraw-Hill.Penerjemahan: Slamet. Jakarta.

Choirul Lutviansah. (2016). Pengaruh Iklan Shampo Pantene Di Televisi Terhadap Keputusan Pembelian Shampo Di Kota Samarinda Jurnal Ekonomi Syariah Indonesia, 1(1), 1-15.

Hamid, R. S., \& Patra, I. K. (2019). PENGANTAR STATISTIKA UNTUK RISET BISNIS DAN EKONOMI Konsep Dasar dan Aplikasi SPSS versi 25. Banten: $C V$. AA. RIZKY.

https://www.topbrand-award.com/top-brand-index/

Izzuddin, A. (2018). Pengaruh Label Halal, Kesadaran Halal Dan Bahan Makanan Terhadap Minat Beli Makanan Kuliner. Jurnal Penelitian IPTEKS, 3(2), 100-114.

Kalangi Tamengkel \& Walangitan, (2019). Pengaruh Celebrity Endorser Dan Brand Image Terhadap Keputusan Pembelian Shampo Clear. Jurnal Administrasi Bisnis, 8(1), 44. https://doi.org/10.35797/jab.8.1.2019.23499.44-54.

Khuwaroh, K. (2018). Analisis Pengaruh Label Halal, Keamanan Bahan, Promosi, Dan Harga Pada Produk Kosmetik Sariayu Terhadap Keputusan Pembelian Konsumen, Jurnal Riset Ekonomi, Manajemen, Bisnis dan Akuntansi 1(2), 155-172.

Khuwaroh, K., Widarko, A., \& ABS, M. K. (2019). ANALISIS PENGARUH LABEL HALAL, KEAMANAN BAHAN, PROMOSI, DAN HARGA PADA PRODUK KOSMETIK SARIAYU TERHADAP KEPUTUSAN PEMBELIAN KONSUMEN (Studi Kasus Pada Mahasiswi Fakultas Ekonomi Dan Bisnis Angkatan 2015-2018 Universitas Islam Malang). Jurnal Ilmiah Riset Manajemen, $8(05)$.

Kotler and Amstrong (2007). Dasar-Dasar Pemasaran jilid 1, Edisi KesembilanIndeks Jakarta:Erlangga.

Kotler, and Amstron 2012.Prinsip-prinsip Pemasaran Edisi 14. Jakarta: Erlangga.

Lutviansah, C. (2016). Pengaruh iklan televisi shampo Pantene terhadap keputusan pembelian shampo: Survei pada masyarakat Kelurahan Dinoyo Kecamatan Lowokwaru Malang (Doctoral dissertation, Universitas Islam Negeri Maulana Malik Ibrahim). 
Mahendra, M. M., \& Ardani, I. G. A. K. S. (2015). Pengaruh Umur, Pendidikan Dan Pendapatan Terhadap Niat Beli Konsumen Pada Produk Kosmetik The Body Shop Di Kota Denpasar. E-Jurnal Manajemen Universitas Udayana, 4(2).

Mentari, K. (2018). Pengaruh Celebrity Endorser Dan Kualitas Produk Terhadap Keputusan Pembelian Melalui Citra Merek Sebagai Variabel Intervening (Studi Kasus Pada Mahasiswa Fakultas Ekonomi Dan Bisnis Umsu). Jurnal Administrasi Bisnis2(2), 1-137.

Oliver, J. (2013).. Pengaruh Bauran Promosi Shampo Hijab Terhadap Keputusan Pembelian dan Pengaruhnya Terhadap Kepuasan Konsumen di Kota Bogor Journal of Chemical Information and Modeling, 53(9), 1689-1699. https://doi.org/10.1017/CBO9781107415324.004.

Rachma, N., \& Hufron, M. (n.d.). Pengaruh Celebrity Endorser dan Brand Association terhadap Keputusan Pembelian Shampo Rejoice Hijab 3in1 Malang Journal of Chemical Information and Modeling Email : ratulolye@gmail.com. 105-118.

Rizki \& Agung, (2017). Pengaruh Kualitas Produk, Citra Merek Dan Celebrityendorser Terhadap Keputusan Pembelian Shampo Sunsilk Pada Indomaret Wilayah Pasarminggu Jakarta Selatan Jurnal Ilmu Manajemen Oikonomia. Jurnal Ilmu Manajemen Oikonomia, 13(2), 1-11.

Salim, M., \& Bachri, S. (2014). Pengaruh Celebrity Endorser terhadap Keputusan Pembelian Produk di Indonesia (Penelitian Online). Jurnal Aplikasi Manajemen, 12(2), 230-238.

Saputra (2017).Pengaruh Iklan Dan Penjualan Personal Terhadap Keputusan Pembelian Shampo Lifebuoy Di Kota Surabaya jurnal ilmu menejemen oikonomia: 6, 5-9.

Shimp, T. A. (2007). Integrated Marketing Communication in Advertising and Promotion 7th Edition. Thompson. Ohio. Terjemahan R. Syahrial dan D.A. Sari. Periklanan Promosi Aspek Tambahan Komunikasi Pemasaran Terpadu. Edisi Ke-7. Jilid 1. Jakarta: Erlangga.

Sugiyono. (2012).Statistika Untuk Penelitian. Bandung: Alfabeta.

Suryadi (2006).Model Kausal Kesadaran,Pelayan,Kepatuhan Wajib Pajak, Dan Pengaruhnya Terhadap Kinerja Penerimaan Pajak, Jurnal Keuangan Publik 1:105121.

Widyaningrum, P. W. (2017). Pengaruh Label Halal dan Celebrity Endorser terhadap Keputusan Pembelian (Survei pada Konsumen Wardah di Ponorogo). JESI (Jurnal Ekonomi Syariah Indonesia), 6(2), 83-98.

Wulandari, N., \& Nurcahya, I. (2015). Pengaruh Celebrity Endorser, Brand Image, Brand Trust Terhadap Keputusan Pembelian Clear Shampo Di Kota Denpasar. E-Jurnal Manajemen Universitas Udayana, 4(11), 3909-3935.

Zubaidah (2016).Pengaruh Harga Dan Iklan Televisi Terhadap Keputusan pembelian Shampo Sunsilk Di Kalangan mahasiswi universitas Palembang Jurnal Manajemen dan Organisasi,1(1), 1-9

Zulkifli, I (2019). Pengaruh Periklanan Islami Terhadap Keputusan Pembelian Produk 
Shampo Hijab Sunsilk Clean And Fresh Pada Mahasiswi Universitas Islam Riau, Jurnal Ekonomi Syariah Indonesia 1(1), 59-73. 